\title{
Community Based Entrepreneurship in Coastal Communities: The Impact on the Environment and Economic Empowerment
}

\author{
Oktaviani Adhi Suciptaningsih ${ }^{1}$, Sucihatiningsih Dian Wisika Prajanti ${ }^{2}$, Dewi Liesnoor \\ Setyowati ${ }^{3}$, Agustinus Sugeng Priyanto ${ }^{4}$ \\ \{osuciptaningsih@yahoo.co.id ${ }^{1}$, dianwisika@yahoo.com ${ }^{2}$, \\ liesnoor@yahoo.co.id ${ }^{3}, \underline{\text { at_spriyanto@mail.unnes.ac.id }}{ }^{4}$ \}
}

Universitas PGRI Semarang, Jl. Dr. Cipto-Lontar, Semarang, Indonesia ${ }^{1}$, Universitas Negeri Semarang, Jl. Sekaran Raya, Semarang, Indonesia ${ }^{234}$

\begin{abstract}
The study aims to analyze community-based entrepreneurship in coastal communities to see the impacts on the environment and economic empowerment. This study employed a qualitative descriptive research design tha was a case study. The research subjects were pindang makers, while the informants were home industry instructors and the community of Tambaksari Village. The study applied four data collections techniques, namely observation, in-depth interviews, focus group discussions, and documents. To check the validity of the data, triangulation was utilized. Furthermore, the study used qualitative data analysis techniques as the basis for analyzing the data that had been obtained. The results of the study indicated that empowerment through community-based entrepreneurship optimized the creativity of all components in coastal communities, created new jobs, and preserved local cultures as well as environment. The community-based entrepreneurship increased the community income so that it could encourage an economic independence and improve quality of life without ignoring local wisdoms in environmental management. In short, the community-based entrepreneurship model could be applied in the coastal areas of Central Java.
\end{abstract}

Keywords: Entrepreneurship, Coastal Communities, Environment, Empowerment.

\section{Introduction}

Indonesia has a coastline of $54,716 \mathrm{~km}$ with an area of $1,904,569 \mathrm{~km}^{2}$. Indonesia ranks second after Canada (Coastline length: 202,800 km with area: 9,984,670 $\mathrm{km}^{2}$ ) in the list of countries with the longest coastline in the world. Sea and coastal areas are very important areas for most Indonesian people. Nearly $60 \%$ of the total population of Indonesia, live and move in the sea and coastal areas. Coastal communities are people who live and carry out socio-economic activities related to coastal and marine resources. They have a high dependence on the potential and condition of coastal marine resources. The livelihoods of coastal communities are divided into two groups, namely fisheries groups including owner fishermen, fishermen workers, fish cultivators/ other marine organisms, fish traders, fish processors, suppliers of fisheries production facilities. Whereas the non-fishery group includes marine/ coastal tourism service providers, marine transportation service providers, community groups that utilize non-living marine and coastal resources for their lives [1]. 
Coastal communities have diverse characteristics and problems, including open culture and limited infrastructure. They also face problems like their lives depend on natural resources, economic activities are strongly influenced by weather and seasons, and the role of markets have a crucial part in developing community activities. Coastal communities are generally considered to be part of the poorest groups of people $[1,2,3]$ and marginalized $[4,5$, $6]$.

Until now, fisheries development programs have only focused more on the economic growth of fisheries industrialization that does not always bring a positive impact on the economic income of the community [8]. This is also experienced by the people of Tambaksari Village, one of the villages in the coastal region of Central Java. Most of the people work in the fish processing industry, which is 1,205 people, $60 \%$ of them work in the cottage industry. The amount of pindang (processed fish products made from a combination of boiling and salting) production in a day can reach $12,500 \mathrm{~kg}$ with a net profit of Rp. 67,500,000 per day. The advantage of pindang fish production per year is around Rp. 24,300,000,000. Although the benefits obtained are quite high but they have not been able to prosper the community.

The government together with the private sector and universities have made various efforts to improve the economy of the people in Tambaksari Village, but the results have not been maximized. Thus far, the empowerment programs are mostly still top-down, policyoriented and physical nature, for example, the provision of tools [9], the provision of fund, and the provision of various types of entrepreneurial training. Empowerment is not based on community needs. The various empowerment programs were misdirected and ended in a fail. Apart from that, it has an impact on the surrounding environment. The coastal community empowerment program should have been done comprehensively not only physical aspects but also the cognitive realm of the instructor. The basic activity that can be done is to provide community-based entrepreneurship education so that there is a change in mindset and proceed with the action. This is because the main factor in the process of home industry pemindangan (the process of preserving fish using salting and heating techniques) is pemindang (pindang maker). Pemindang must be involved in the identification of needs so that various activities in the process of empowering the home industry of pemindangan can be right on target. Therefore, this study was conducted to analyze the community-based entrepreneurship in coastal communities and see the impacts on the environment and economic empowerment. The results of the analysis were used as the basis for the empowerment model preparation of the home industry players in the coastal communities of Central Java.

\section{Method}

This research is a series of studies on the model of empowerment of home industry players in coastal communities in Central Java. This study used a qualitative descriptive research design that was a case study. The research subjects were pemindang in Tambaksari Village with a total sample of 25 people who were divided into 3 categories, namely small home industry, medium home industry, and advanced home industry. The study sampled 1 small home industry, 19 medium home industry, and 5 advanced home industry. The researcher engaged directly in the process of collecting research data and information. The data collection was carried out by using observation, interviews, focus group discussion, and documents in order to analyze problems comprehensively. Direct observation was applied by researchers and community empowerment experts to directly see the activities of the 
pemindang in performing the pemindangan process. In the focus group discussion, the researcher asked broad questions to obtain responses and trigger discussions among the respondents. The focus group discussion involved the pemindang, home industry instructors and the Tambaksari Village community where information about the problems and the needs of shelters for community-based entrepreneurship education in coastal communities was explored. The documents were employed to see various indicators of success and weaknesses of each activity that had been carried out. Each of these data sources was collected to obtain the data that fits the needs of the research (reliable). The data was then analyzed through descriptive-qualitative methods. The analysis was continuously undertaken from data collection until the research completed.

\section{Result and Discussion}

The results of the observations showed that the pemindang in Tambaksari Village (ethnic Javanese) were still bound by cultural values and norms in their lives, including in the activities of pemindangan. Those values are wedi (fear), isin (shame) and ewuh pakewuh (shyness). The application of the values of wedi, isin and ewuh pakewuh was seen in the pattern of patron-client interactions between the owners of pindang businesses and the pindang workers. The use of the wedi value in the process of brooding could be seen that the pindang laborers were afraid of making mistakes in the process of pemindangan so that it caused losses to the owner of the pemindang business. One of the implementation of islamic value was a shy labourer. If he were forever a labourer, the community would consider them fail in developing their potentials. Whereas the application of the ewuh pakewuh value was the feeling of being reluctant if you were forever a pindang worker, so it would be troublesome for the employers as well as the owners. In general, the community made pindang laborers get the knowledge of how to do good pemindangan. Patron-client relations with the Tambaksari Village community not only created a class of business owners and laborers but also created senior and junior classes. It could happen because most of the business owners were sesepuh (elder people in the community) who had more experience in various aspects, while most laborers were young people. Therefore the pindang workers highly respected the owner of the pemindangan business not only because of the employer-labour relationship but also because of the senior-junior relations that were still bound by cultural customs.

The empowerment that had been carried out so far has not paid attention to the values of wedi, isin and ewuh pakewuh. Thus, the workers tended to be reluctant to follow some rules. Workers were very respectful of business owners, whatever the business owner said, they would follow because they were eldery who were full of life values, including the value of entrepreneurship.

Based on the results of interviews and focus group discussions, business owners played a role as the companion to the pemindangan home industry because they had a big influnce among the pindang workers in particular and the people of Tambak Sar in general. Pemindangan business owners were involved directly in the process of planning, implementing and evaluating empowerment. This was undertaken because empowering coastal communities meant creating opportunities for coastal communities to determine their needs, plan and carry out their activities, which ultimately created permanent independence in the life of the community itself [10]. 
The results of the study showed: (1) that empowerment through community-based entrepreneurship optimized the creativity of all components in coastal communities. The pattern of patron-client interaction that was influenced by traditional values, namely wedi, isin and ewuh pakewuh had been successfully used to empower the pemindang in Tambaksari Village. Patron-client relations were the special cases of relations between two people, most of which involved instrumental friendship, in which a person with a higher social position (patron) used the influence of his resources to provide protection or benefits, or both to people who had lower social status (client). The client then repaid the gift by providing support and assistance including personal services to the patron [11]. The involvement of escorts from the elements of the owner of the business who was at the same time considered as village elders provided convenience in the mentoring process. The influence made business owners more free to give direction during the empowerment process, including when they asked various components to take part according to their portion, for example: asking the Village Head to convey to the Kendal District Fisheries and Marine Service to facilitate entrepreneurship training activities for pindang workers and the owners of pemindangan business, asking other pindang business owners to take part in the training and give permission to their pindang workers to take part in alternating training activities and ask pindang workers to attend training in an orderly manner. (2) the empowerment created new jobs. Based on the results of the training followed by pindang workers and pindang business owners, they succeeded in creating new jobs, the number of pemindang showed a significant change in the number of business owners of pemindangan. Preliminary data showed that the number of pindang business owners were about 25 people, then it increased to 57 people. In additon, there were new types of businesses which came from diverse pindang fish processing, including pindang nuggets, pindang fish sticks, abon pindang, and others. (3) the empowerment reserved local culture and environment. Before involving the business owner of the pemindangan as an instructor, the pemindangan process had not yet met health standards, for example they did not remove pindang feces in the cleaning process, while it should be disposed in order to slow down decay. Moreover, they washed pindang fish in the basin which should be washed under the running water in order to be hygienic. They also disposed the fish waste in the river while the fish waste should be collected and disposed in the dump. After involving the instructor of the business owner, the habit changed, the owner of the business began to ask the pindang workers to remove fish feces from the belly of the pindang, wash the fish under the running water and collect the waste of pindang fish to be used as catfish food. The words of the business owners as well as instructor (those who were trusted by the village elders) were more heeded and quickly carried out. As a result, the rivers around the community settlements that were once contaminated with pindang fish, smelly and murky, now it became clean.

During the process of empowering, the role of instructor from the elements of the pemindangan business owrner as well as the elders of Tambaksari Village had the most important and dominant role in determining the success of each empowerment activity. In the community-based empowerment process, various stages of activities were carried out without abandoning cultural values as the identity of the community, namely Javanese ethnicity which was identical with Javanese coastal culture. This is consistent with Ting-Toomey's statement [12] about social identity theory that said social (or socio-cultural) identity can include ethnic membership identity, social class identity, family role, and personal identity. It can include any unique attributes associated with oneself who are individual and have comparisons with others. 
The benefit obtained was an increase in community income so that it could build economic independence and improve quality of life without ignoring local wisdom in environmental management.

\section{Conclusion}

Community-based empowerment efforts in Central Java need to be directed not only to overcome economic problems but also cultural problems. Since the implementation of empowerment approach is still partial, especially only related to increasing factors of production, it is recommended that empowerment requires the application of concepts and multidimensional efforts for all aspects including social, economic and cultural aspects. Therefore, it should use two-track approaches, namely a top-down approach and a bottom-up approach. A top-down approach is implemented by giving an active role in the decisionmaking process of fishing community policies, while a bottom-up approach is performed by strengthening communities at the grassroots level. In addition, a bottom up approach promotes the principle of local community involvement and participation which becomes the important parts of instructor activities.

Acknowledgments. I want to express my great appreciation to Ministry of Research, Technology and Higher Education (Republic of Indonesia) who has funded this research in the Doctoral Dissertation Research scheme (Kontrak Penelitian Disertasi Doktor No: 84.18.3/ UN37/PPK.3.1/2019). 


\section{References}

[1] Lasabuda, R.: Pembangunan Wilayah Pesisir dan Lautan dalam Perspektif Negara Kepulauan Republik Indonesia. Jurnal Ilmiah Platax. Vol.1(2). pp. 92-101 (2013)

[2] Ahmed, N., Troell, M., Allison, A.H., Muir, J.F.: Prawn Postlarvae Fishing in Coastal Bangladesh: Challenges for Sustainable Livelihoods. Marine Policy Vol. 34 (2). pp. 218-227 (2010)

[3] Jentoft, S., Onyango, P., Islam, M.M.: Freedom and Poverty in the Fishery Commons. International Journal of the Commons. Vol. 4 (1). pp. 345-366 (2010)

[4] Rukin, Rahman, B., Toha, A., Gianawati, N.D.: Coastal Rural Community Economic Development As a Poverty Reduction Efforts. The International Journal of Social Sciences and Humanities Invention. Vol. 5 (4). pp. 4627-4633 (2018)

[5] Béné, C.: When Fishery Rhymes with Poverty: A First Step Beyond the Old Paradigm on Poverty in Small-Scale Fisheries. World Development. Vol. 31 (6). pp. 941-975 (2003)

[6] Kayak, P.K., Oliveira, L.E., Berkes, F.: Resource degradation, marginalization, and poverty in small-scale fisheries: threats to social-ecological resilience in India and Brazil. Ecology and Society. Vol. 19(2). pp. 73-86 (2014)

[7] Kurniawan, A.: Education for Marginalized Communities As Alternative Solution an The Coastal Areas. Cendekia Vol. 14 (2). pp. 175-192 (2016)

[8] Menon, A., Sowman, M., Bavinck, M.: Rethinking Capitalist Transformation of Fisheries in South Africa and India. Ecology and Society. Vol. 23(4). pp. 27-38 (2018)

[9] Suciptaningsih, A.S., Prajanti, S.D.W., Setyowati, D.L., Priyanto, A.S., Maretta, Y.A.: Improving the Innovation of Appropriate Technology in the Home Industry of Pemindangan in Coastal Communities of Tambaksari Village. Journal of Environmental Management and Tourism. Vol. 10(1). pp. 32-38 (2019).

[10] Alkadrie, S.I.T.: Analisis Pengelolaan Sumber Daya Perikanan dengan Pemberdayaan Ekonomi Masyarakat Pesisir di Kecamatan Pemangkat Kabupaten Sambas. Tesis. Sekolah Pascasarjana IPB (2008)

[11] Sinaga, H., Widiono, S., Irnad.: Pola Hubungan Patron-Klien pada Komunitas Nelayan di Kelurahan Malabro Kecamatan Teluk Segara Kota Bengkulu. AGRISEP Vol. 15 (2). pp. 167 - 176 (2015)

[12] Ting-Toomey, S.: Identity Negotiation Theory. In J. Bennett (Ed.), Sage Encyclopedia of Intercultural Competence. Vol. 1. pp. 418-422 (2015) 